\title{
Ternary Nanocomposite of ZnFe204/a-Fe203/ZnO; Synthesis via Coprecipitation Method and Physical Properties Characterization
}

Somayeh Shams ( $\sim$ somayeh.shams@srbiau.ac.ir)

Islamic Azad University https://orcid.org/0000-0002-3783-6413

\section{Zahra Sheibanizadeh}

Islamic Azad University

\section{Zahra Khalaj}

Islamic Azad University

Original Research Full Papers

Keywords: ZnFe2O4/a-Fe2O3/ZnO nanocomposite, Spinel nanoparticles, Ternary nanocomposite powder, Calcination effects, Optical transition

Posted Date: February 15th, 2021

DOl: https://doi.org/10.21203/rs.3.rs-171333/v1

License: (c) (i) This work is licensed under a Creative Commons Attribution 4.0 International License. Read Full License 


\title{
Ternary Nanocomposite of $\mathrm{ZnFe}_{2} \mathrm{O}_{4} / \alpha-\mathrm{Fe}_{2} \mathrm{O}_{3} / \mathrm{ZnO}$; Synthesis via Coprecipitation Method and Physical Properties Characterization
}

\author{
Somayeh Shams ${ }^{\mathrm{a}, \mathrm{b}}$, Zahra Sheibanizadeh ${ }^{\mathrm{b}}$ and Zahra Khalaj ${ }^{\mathrm{c}, *}$ \\ ${ }^{a}$ Plasma Physics Research Center, Science and Research branch, Islamic Azad University, Tehran, Iran; \\ ${ }^{b}$ Young Researchers and Elite Club, Shahr-e-Qods branch, Islamic Azad University, Tehran, Iran \\ ${ }^{c}$ Physics Department, Shahr-e-Qods branch, Islamic Azad University, Tehran, Iran
}

\begin{tabular}{l}
\multicolumn{1}{c}{ A R T I C L E H I S T O R Y } \\
\hline Received: \\
Revised: \\
Accepted: \\
DOI:
\end{tabular}

\begin{abstract}
ZnFe}_{2} \mathrm{O}_{4} / \alpha-\mathrm{Fe}_{2} \mathrm{O}_{3} / \mathrm{ZnO}$ ternary transition metal oxides nanocomposite powder was successfully synthesized by facile coprecipitation method directly from metalorganic precursors within 4 hours processing time considerably shorter than other reported methods. To study post-synthesis thermal treatment effects on physical properties calcination process was applied at $500{ }^{\circ} \mathrm{C}, 600{ }^{\circ} \mathrm{C}$ and $700{ }^{\circ} \mathrm{C}$ individually in furnace for one hour. The structure, phase formation, morphology and optical features of the samples were characterized by means of powder X-ray diffraction, scanning electron microscopy and UV-Visible spectroscopy. The results show formation of pure and homogeneous composites comprised of nanoparticles with good crystallization in narrow range of crystallite size between $25 \mathrm{~nm}-39 \mathrm{~nm}$. The particle sizes were also estimated to be in the range of $48 \mathrm{~nm}-93 \mathrm{~nm}$. The optical property was studied by recording the absorbance spectrum in the range of $200 \mathrm{~nm}-700 \mathrm{~nm}$. The absorption pattern illustrated that the product can be driven by both UV and visible wavelengths with a good efficiency which is more desirable for intended applications like photocatalytic activities compare to the individual components. By using Tauc's method the allowed direct band gap energy and indirect band gap energy of the prepared nanocomposite was estimated to be around $2.28 \mathrm{eV}$ and 2.75 $\mathrm{eV}$, respectively.
\end{abstract}

Keywords: $\mathrm{ZnFe}_{2} \mathrm{O}_{4} / \alpha-\mathrm{Fe}_{2} \mathrm{O}_{3} / \mathrm{ZnO}$ nanocomposite, Spinel nanoparticles, Ternary nanocomposite powder, Calcination effects, Optical transition.

\section{INTRODUCTION}

Composites with all phases in nanoscopic dimensions have high potential of applications in various areas like catalytic activities also for homogeneous doping and incorporation in materials matrix for filtering and sensing, nowadays [1-7]. In this class of heterogeneous materials, binary composites of zinc ferrite $\left(\mathrm{ZnFe}_{2} \mathrm{O}_{4}\right)$, hematite $\left(\alpha-\mathrm{Fe}_{2} \mathrm{O}_{3}\right)$ and zinc oxide $(\mathrm{ZnO})$ as the highly interesting semiconducting transition metal oxides (TMOs) have received much research attention $[1,8,9]$. However, successfully preparation of ternary composite of these nanoparticle through one approach has been reported in few works yet $[10,11]$.

As the most practical application for this class of composite photocatalytic activities such as water pollution degradation [10-13], $\mathrm{CO}_{2}$ reduction [14], photoelectrochemical (PEC) water splitting and hydrogen production $[5,15,16]$ and PEC oxidation of water [17] have become topics of interest as well as biotechnology and nanomedicine [18-23] applications.

*Address correspondence to this author at the Department of Physics, Faculty of Shahr-e-Qods branch, Islamic Azad University, P.O. Box: 37515-374, Tehran, Iran, Tel: +98-468-96-507; E-mails: z.khalaj@ qodsiau.ac.ir
Although, these compound materials individually have many significant properties but faces limitations for some applications. As a n-type semiconductor $\alpha-\mathrm{Fe}_{2} \mathrm{O}_{3}$ is non-toxic, photochemically highly stable with narrow bandgap also is abundant in nature, however, rapid recombination of photogenerated carriers and low conductivity greatly limits its PEC performance [24-27].

The n-type $\mathrm{ZnO}$ is a widely used photocatalyst, possess highly ability of oxidation, cost efficiency, versatility in synthesis and ease of crystallization, whereas, pure zinc oxide with large amount of band gap energy ca.3.2 eV is weak to take advantage of absorbing visible wavelengths of light spectrum $[28,29]$ to generate charge carriers. These nanoparticles as complements in the form of composite reduce or cover disadvantageous properties of each other for targeted applications. For instance, in the case of photocatalytic applications despite of the mentioned disadvantages of hematite and zinc oxide, spinel zinc ferrite has demonstrated that excellently is driven by incident visible light due to its band gap energy which is around $2 \mathrm{eV}$ [30], in addition, companion of this p-type in the composite is a promising route to suppress electron-hole recombination [31]. 
Moreover, $\mathrm{ZnFe}_{2} \mathrm{O}_{4}$ has vast range of applications due to its amazing electrical and magnetic properties [16, 32-34]. Consequently, ternary composite of $\mathrm{ZnFe}_{2} \mathrm{O}_{4} / \alpha-\mathrm{Fe}_{2} \mathrm{O}_{3} / \mathrm{ZnO}$ is more efficient for photocatalytic processes compare with the individual components.

There are different methods to prepare TMO semiconductor nanocomposites, including sol-gel method [6, 35-37], sonochemical [38, 39], hydrothermal [1, 10, 11], microwave combustion [34, 40, 41], and coprecipitation [42, 43]. Among various chemical methods for synthesis, coprecipitation process has several advantages compare with other methods including, good homogeneity, low cost, high purity of product and not requiring organic solvents. Moreover, the experimental conditions play a very important role in determining the shape, size and purity and hence the drastic modifications of the properties [16, 44].

In this work, experimental conditions of preparing ternary nanocomposite of semiconducting TMOs by single coprecipitation approach is presented in detail. One of the important factor for synthesis this nanocomposite is reducing time without any effect on quality. The reported process time of synthesis of TTMOs composite were more than 14 hours [11] and 30 hours [10] via hydrothermal method . In this paper the preparation time was just 4 hours with good quality and characteristics nanocomposite product which is much more economical and suitable for industrial production. Furthermore, the effects of different temperatures of postsynthesis thermal treatment on the structure, phase formation, morphology and optical properties have been studied by employing X-Ray diffraction (XRD), Scanning electron microscopy (SEM) and UV-Visible spectroscopy as the characterization techniques.

\section{MATERIALS AND METHOD}

\subsection{Materials}

Iron (III) chloride hexahydrate $\left(\mathrm{FeCl}_{3} \cdot 6 \mathrm{H}_{2} \mathrm{O}\right.$, Molar Mass: $\left.270.33 \mathrm{gmol}^{-1}\right)$, Zinc chloride $\left(\mathrm{ZnCl}_{2}\right.$, Molar Mass: 136.30 gmol $\left.{ }^{-1}\right)$, Hydrate ethanol $\left(\mathrm{C}_{2} \mathrm{H}_{8} \mathrm{O}_{2}\right)$ and Sodium hydroxide
( $\mathrm{NaOH}$, Molar Mass: 40.00 gmol $^{-1}$ ) are the Merck company materials which were used in this work without any purification as the precursors.

\subsection{Synthesis}

In this method, $68.143 \mathrm{~g}$ of Zinc chloride $\left(\mathrm{ZnCl}_{2}\right)$ and $162.2 \mathrm{~g}$ of Iron (III) chloride $\left(\mathrm{FeCl}_{3}\right)$ were be separately grinding in mortar then dissolved in de-ionized (DI) water to produce two different solutions, were denoted as solution 1 and solution 2 respectively. In the next step, solution 2 was added into solution 1 under stirring. Sodium hydroxide $(\mathrm{NaOH})$ solution was added to the mixture, which was heated and stirred at $c a$. $60{ }^{\circ} \mathrm{C}$ for 30 min until liquid with $\mathrm{pH} 12$ was obtained. The molar ratio of $\mathrm{Zn} / \mathrm{Fe}$ was 1:2.

The pre-treated solution was washed with ethanol and DI water respectively. Heat treatment of the powder product was carried out at $100{ }^{\circ} \mathrm{C}$ for 3 hours in the oven. The synthesized nanocomposite was divided into three equal parts and heated them at $500{ }^{\circ} \mathrm{C}, 600{ }^{\circ} \mathrm{C}$ and $700{ }^{\circ} \mathrm{C}$ individually under atmosphere condition to study annealing temperature effects on their physical properties. As the final step of purification, ultrasonic bath was applied to dissolve powders in ethanol for $45 \mathrm{~min}$ then dried at ambient temperature after filtering.

\subsection{Characterization}

A PANalytical X'Pert High Score X-ray DiffractometerPhilips PW1730 equipped with $\mathrm{Cu}$ anode $(\lambda=0.154060 \mathrm{~nm})$ was used in the crystallography investigation in this work. Diffraction was carried out at room temperature within $2 \Theta$ angular range of $9.97^{\circ}-79.97^{\circ}$ with constant step size of $0.05^{\circ}$. The morphology of the synthesized ternary nanocomposite powder was characterized by employing scanning electron microscopy (SEM) model KYKY-EM3200, operated at an acceleration voltage of. $26 \mathrm{kV}$. UV-Vis absorption spectrum was obtained using SHIMADZU UV-1800 spectrophotometer $(50-60 \mathrm{~Hz}, 240 \mathrm{~V})$. DI water was used as the background correction material the suspension was

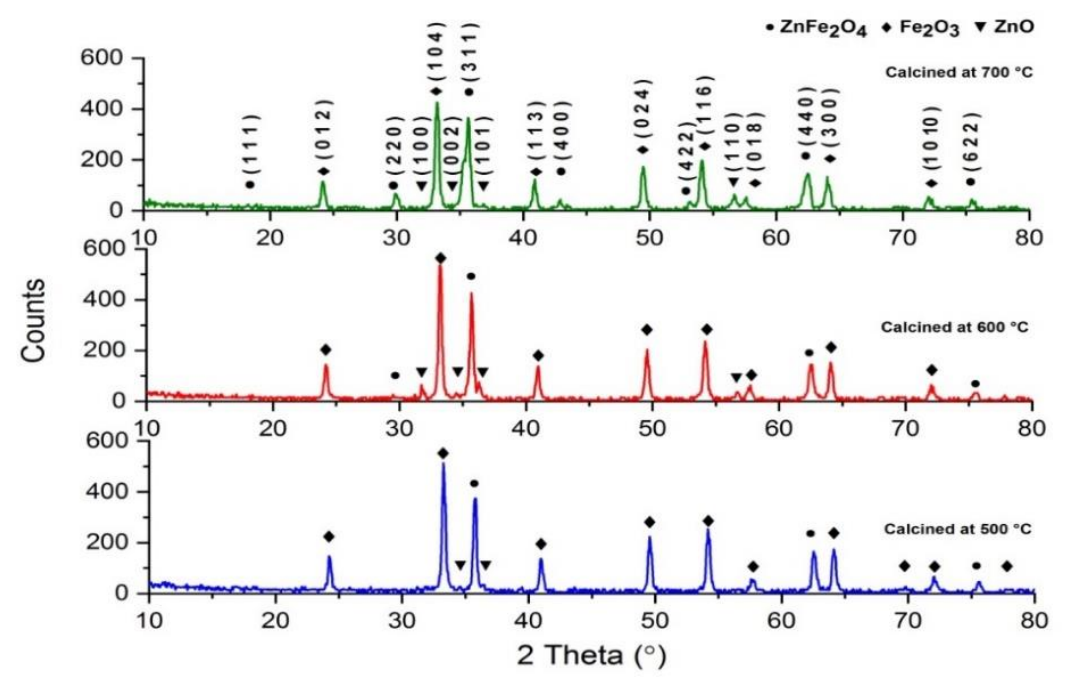

Fig.1 XRD patterns of $\mathrm{ZnFe}_{2} \mathrm{O}_{4} / \alpha-\mathrm{Fe}_{2} \mathrm{O}_{3} / \mathrm{ZnO}$ nanocomposite calcined at 500 ${ }^{\circ} \mathrm{C}, 600{ }^{\circ} \mathrm{C}$ and $700{ }^{\circ} \mathrm{C}$ 
scanned in the region from $200 \mathrm{~nm}$ to $700 \mathrm{~nm}$ with $1 \mathrm{~nm}$ steps in the quartz cuvette of $1 \mathrm{~cm}$ path length.

\section{RESULTS AND DISCUSSION}

\subsection{Structural Investigation}

Structure and phase composition of the synthesized powders was evaluated by employing powder X-ray diffraction (XRD) method. The XRD patterns obtained from ternary nanocomposites synthesized by coprecipitation method after thermal treatment process at $500{ }^{\circ} \mathrm{C}, 600{ }^{\circ} \mathrm{C}$ and $700{ }^{\circ} \mathrm{C}$ are presented in Figure1, along with PANalytical fitting and data from the literature [45-47]. Highly intense sharp peaks with small full width at half maximum (FWHM) in the graphs indicate products comprised of good crystallized nanoparticles. All the diffraction peaks denoted on the graphs are matched with the reference numbers, (ICSD NO. 98-0058878) for cubic lattice system zinc ferrite, the prominent peak (311) is located at $2 \Theta \approx 35.72^{\circ}$, as well as (440) and (622) planes occurred at $62.51^{\circ}$ and $75.55^{\circ}$, respectively. The hematite nanoparticle with rhombohedral unit cells illustrated the prominent peak (104) located at $2 \Theta \approx 33.20^{\circ}$ in addition to other planes (024), (012), (116), (113), (300), (1010), (018) at $49.57^{\circ}, 24.22^{\circ}, 54.17^{\circ}, 40.95^{\circ}, 64.10^{\circ}, 72.07^{\circ}, 57.77^{\circ}$, respectively in order of their intensities matched with reference card (ICSD NO. 98-001-2729). The hexagonal zinc oxide nanocrystals peaks are (101) revealed at $36.39^{\circ}$ and (002) around $34.56^{\circ}$ matched with (ICSD NO. 01-075-0576). Raising calcination temperature resulted in formation of new planes of $\mathrm{ZnO}$ and $\mathrm{ZnFe}_{2} \mathrm{O}_{4}$. In contrast, this thermal treatment process causes decline in intensity of hematite peaks at $700{ }^{\circ} \mathrm{C}$ and vanishing some tiny peaks of this component. As can be seen, $600{ }^{\circ} \mathrm{C}$ provides suitable condition for $\mathrm{ZnO}$ nanocrystals for growing up also getting mature by exposing (100) and (110) planes positioned at $31.7^{\circ}$ and $56.68^{\circ}$ respectively toward incident $\mathrm{X}$-rays, whereas, condition of $700^{\circ} \mathrm{C}$ provides this chance for $\mathrm{ZnFe}_{2} \mathrm{O}_{4}$ crystals. As is shown, (111), (220), (400) and (422) located at $2 \Theta \approx 18.24^{\circ}, 29.96^{\circ}, 42.93^{\circ}$ and $53.17^{\circ}$ respectively are the new planes of zinc ferrite which

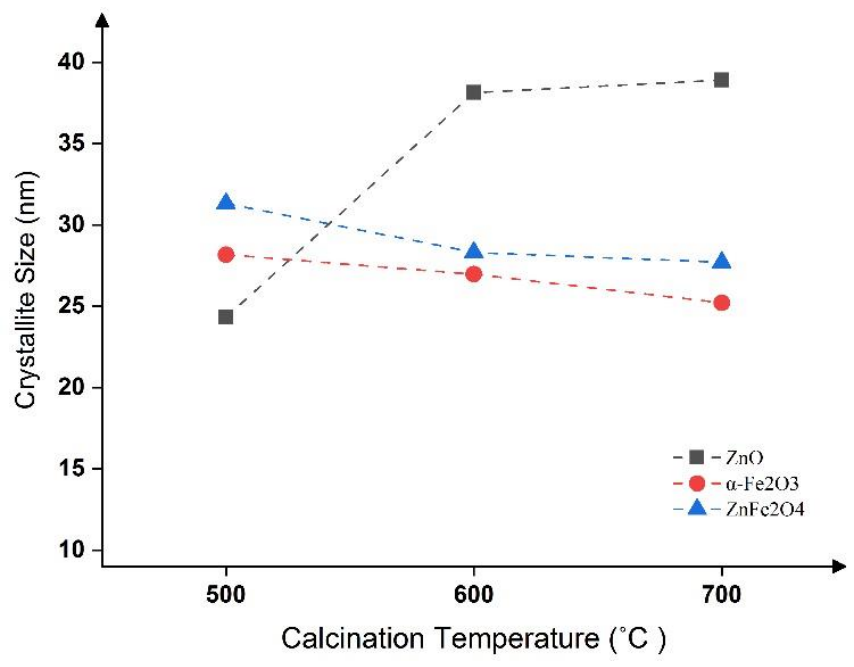

Fig.2 Effect of calcination temperature on the crystallite size of the $\mathrm{ZnFe}_{2} \mathrm{O}_{4} / \alpha-\mathrm{Fe}_{2} \mathrm{O}_{3} / \mathrm{ZnO}$ composite components

were emerged in the pattern after thermal process at $700{ }^{\circ} \mathrm{C}$. The effect of calcination temperature on the crystallite size is presented in Figure 2. The crystallite size was estimated using the Debye-Scherrer equation:

$$
\mathrm{D}=\frac{K \lambda}{\beta \cos \theta}
$$

Where $\mathrm{D}$ is the crystallite size in $\mathrm{nm}, \mathrm{K}$ is crystallite shape factor (0.89), $\lambda$ is $\mathrm{X}$-ray wavelength coming from $\mathrm{Cu}-\mathrm{K} \alpha$ $(0.154060 \mathrm{~nm}), \beta$ is FWHM in radian and $\Theta$ is Bragg diffraction angle. Crystal size at different temperatures were estimated based on average of calculated size for all the peaks ascribed to each component reported in Table 1. The diagrams in Figure 2 indicate gentle downward trends for $\alpha-\mathrm{Fe}_{2} \mathrm{O}_{3}$ and spinel $\mathrm{ZnFe}_{2} \mathrm{O}_{4}$ crystallite size by increasing temperature from $500{ }^{\circ} \mathrm{C}$ to $700{ }^{\circ} \mathrm{C}$. Decrease in crystal size and intensity of peaks indexed to $\alpha-\mathrm{Fe}_{2} \mathrm{O}_{3}$ is in good agreement to published works [10].

Tab.1 Interplanar spacing, peak intensity and crystal size of ternary nanocomposites components synthesized by coprecipitation method calcined at $500{ }^{\circ} \mathrm{C}, 600{ }^{\circ} \mathrm{C}$ and $700{ }^{\circ} \mathrm{C}$

\begin{tabular}{|c|c|c|c|c|c|}
\hline Component & $\begin{array}{l}\text { Prominent } \\
\text { Peak }\end{array}$ & $\begin{array}{c}\text { Calcination } \\
\text { Temperature }{ }^{\circ} \mathrm{C}\end{array}$ & $\begin{array}{c}\text { Peak } \\
\text { Intensity }\end{array}$ & $\begin{array}{c}\text { Interplanar Spacing } \\
d_{\text {hkl }}(\mathbf{n m})\end{array}$ & $\begin{array}{c}\text { Crystallite Size } \\
\text { D (nm) }\end{array}$ \\
\hline \multirow{3}{*}{$\mathrm{ZnFe}_{2} \mathrm{O}_{4}$} & \multirow{3}{*}{$\left(\begin{array}{lll}3 & 1 & 1\end{array}\right)$} & 500 & 362 & 0.250974 & 31 \\
\hline & & 600 & 376 & 0.251383 & 28 \\
\hline & & 700 & 354 & 0.251737 & 28 \\
\hline \multirow{3}{*}{$\alpha-\mathrm{Fe}_{2} \mathrm{O}_{3}$} & \multirow{3}{*}{$\left(\begin{array}{lll}1 & 0 & 4\end{array}\right)$} & 500 & 392 & 0.269580 & 28 \\
\hline & & 600 & 523 & 0.269723 & 27 \\
\hline & & 700 & 344 & 0.269304 & 25 \\
\hline \multirow{3}{*}{$\mathrm{ZnO}$} & \multirow{3}{*}{$\left(\begin{array}{lll}1 & 0 & 1\end{array}\right)$} & 500 & 35 & 0.246888 & 24 \\
\hline & & 600 & 76 & 0.247414 & 38 \\
\hline & & 700 & 27 & 0.247744 & 39 \\
\hline
\end{tabular}


However, this trend for $\mathrm{ZnFe}_{2} \mathrm{O}_{4}$ crystals can be elucidated by considering lattice dislocation removal. Therefore, atoms are more likely to find best position in the crystal structure in higher kinetic energy via raising the temperature, this yielded in forming nanoparticles with higher crystallinity, instead of increasing the size. Changing in the $\mathrm{ZnFe}_{2} \mathrm{O}_{4}$ lattice constant $\left(\mathrm{a}_{500}=0.8350 \mathrm{~nm}, \mathrm{a}_{600}=0.8354 \mathrm{~nm}\right.$ and $\left.\mathrm{a}_{700}=0.8400 \mathrm{~nm}\right)$ toward standard length and reported value [48] can confirm this claim. Zinc ferrite lattice constant was calculated using the following equation:

$$
a=d_{h k l} \sqrt{h^{2}+k^{2}+l^{2}}
$$

$\mathrm{ZnO}$ crystals reached larger size at higher treatment temperature which is in good agreement to the reported works [47]. Variation of interplanar spacing and intensity of prominent peaks as a function of calcination temperature are reported in Table 1.

\subsection{Morphology Investigation}

SEM images of the $\mathrm{ZnFe}_{2} \mathrm{O}_{4} / \alpha-\mathrm{Fe}_{2} \mathrm{O}_{3} / \mathrm{ZnO}$ powders given in Figure 3 illustrate morphology of the synthesized nanoparticles. Figure 3(a) shows the nanoparticles of the asprepared powder. Thermal treatment effects on shape, size of the nanoparticles and agglomeration of the components are evident in Figures 3(b-d) which are ascribed to powders calcined at $500{ }^{\circ} \mathrm{C}, 600{ }^{\circ} \mathrm{C}$ and $700{ }^{\circ} \mathrm{C}$, respectively. The agglomeration is found to be decreasing after passing calcination at $500{ }^{\circ} \mathrm{C}$ and $600{ }^{\circ} \mathrm{C}$, the nanoparticles are clearly recognizable as free standing spherical particles with smooth surfaces in almost uniform size range. In contrast, the sample calcined at $700^{\circ} \mathrm{C}$ shown increasing in agglomeration which can be explained by coalescence and weight loss [45]. The rang of particle size for all samples were estimated by SEM measurement, Figure 4 illustrates the results. The least diversity in size belongs to the sample calcined at $600^{\circ} \mathrm{C}$ in which size of 25 to 75 percent of the particles are between 73 $\mathrm{nm}-80 \mathrm{~nm}$ range.

Overall, the sizes of nanoparticles prepared in this work under different thermal treatments are between $48 \mathrm{~nm}$ to $93 \mathrm{~nm}$ much smaller than reported size $(100-200 \mathrm{~nm})$ of the same composite prepared by hydrothermal process [11].

\subsection{Optical Investigation}

The UV-Visible absorption spectrum of the $\mathrm{ZnFe}_{2} \mathrm{O}_{4} / \mathrm{Fe}_{2} \mathrm{O}_{3} / \mathrm{ZnO}$ nanocomposite powder calcined at $500^{\circ} \mathrm{C}$ is given in Figure 5. As can be seem from the obtained spectrum, the pattern is different from individual components absorbent behaviour also not similar to the reported spectra for binary or doped composites in the cases of absorption edges and intensities [7, 8, 27, 49]. The two predominant absorption regions are observed between $260 \mathrm{~nm}$ to $340 \mathrm{~nm}$, and a broad region from $340 \mathrm{~nm}$ to $700 \mathrm{~nm}$. The band located at $311 \mathrm{~nm}(3.98 \mathrm{eV})$ indicating presence of $\mathrm{ZnO}$ nanoparticles in the composite. The other characteristic absorption band of
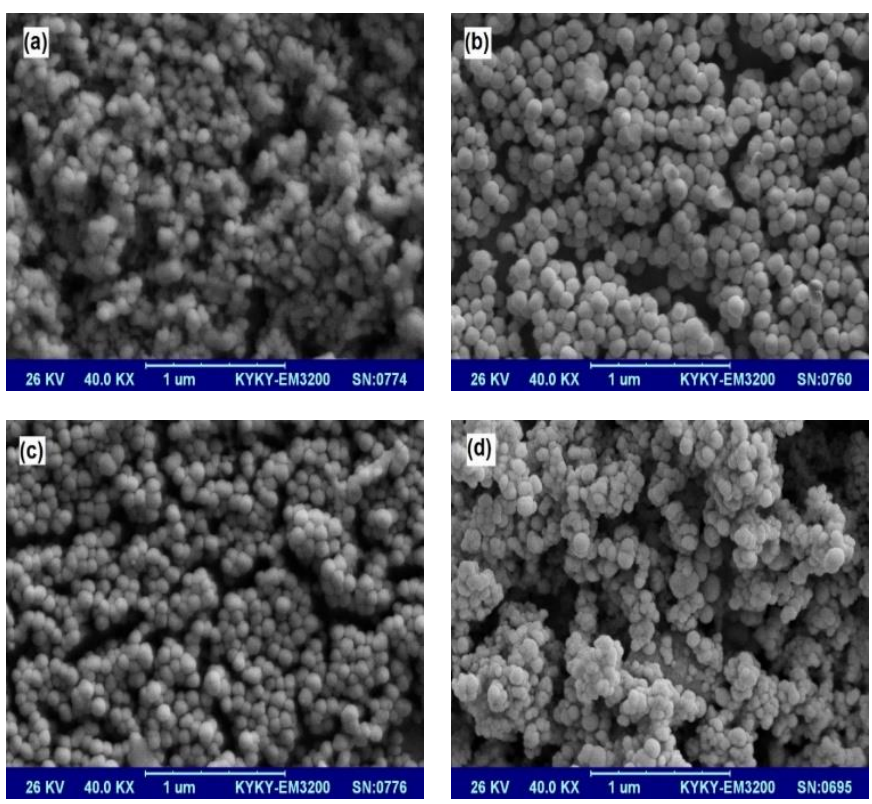

Fig.3 SEM images of the $\mathrm{ZnFe}_{2} \mathrm{O}_{4} / \alpha-\mathrm{Fe}_{2} \mathrm{O}_{3} / \mathrm{ZnO}$ nanocomposite powders: (a) as-prepared, and after calcination at (b) $500{ }^{\circ} \mathrm{C}$, (c) $600{ }^{\circ} \mathrm{C}$ and (d) $700{ }^{\circ} \mathrm{C}$

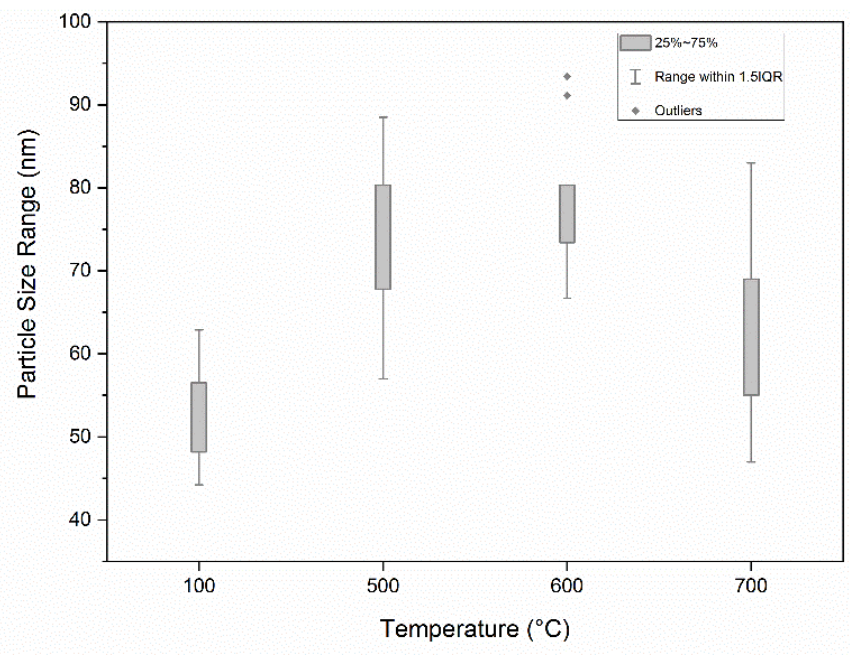

Fig.4 Size range of the $\mathrm{ZnFe}{ }_{2} \mathrm{O}_{4} / \alpha-\mathrm{Fe}_{2} \mathrm{O}_{3} / \mathrm{ZnO}$ nanoparticles versus calcination temperature

$\mathrm{ZnO}$ around $375 \mathrm{~nm}(3.31 \mathrm{eV})$ observed shifted to the longer wavelength as a tinny shoulder at $c a .380 \mathrm{~nm}(3.26 \mathrm{eV})$ likely be masked with hematite absorbance region, therefore, calcination process has illustrated slight red sift in the characteristic peaks $[49,50]$. The broad region as a cumulative wide peak includes bands of $\alpha-\mathrm{Fe}_{2} \mathrm{O}_{3}$ as well as $\mathrm{ZnFe}_{2} \mathrm{O}_{4}$. Transitions in hematite occurred at $c a .361 \mathrm{~nm}(3.43 \mathrm{eV})$ and $617 \mathrm{~nm}(2.00 \mathrm{eV})$ which are ascribed to a ligand-to-metal charge transfer $\left(6 \mathrm{t}_{1 \mathrm{u}} \rightarrow 2 \mathrm{t}_{2 \mathrm{~g}}\right)$ and ligand-free $\left({ }^{6} \mathrm{~A}_{1} \rightarrow{ }^{4} \mathrm{E}\right)$, respectively [11] are in this range of wavelengths. Moreover, evidence of zinc ferrite optical transitions observed around 
$472 \mathrm{~nm}(2.62 \mathrm{eV}), 493 \mathrm{~nm}(2.51 \mathrm{eV})$ are attributed to $\left({ }^{6} \mathrm{~A}_{1 \mathrm{~g}} \rightarrow\right.$ $\left.{ }^{4} \mathrm{~T}_{2 \mathrm{~g}}(\mathrm{D})\right),\left({ }^{6} \mathrm{~A}_{1 \mathrm{~g}} \rightarrow{ }^{4} \mathrm{~A}_{\mathrm{gg}}(\mathrm{G})\right)$ transition, respectively, and 558 $\mathrm{nm}(2.22 \mathrm{eV})$ band with maximum value in this range can be assigned to $\mathrm{O}^{2-}+\mathrm{Fe}^{3+} \rightarrow \mathrm{O}^{-}+\mathrm{Fe}^{2+}$ direct transition and the weak signal at $643 \mathrm{~nm}(1.92 \mathrm{eV})$ can be considered of $\mathrm{O}^{2-}+$ $\mathrm{Fe}^{3+} \rightarrow \mathrm{O}^{-}+\mathrm{Fe}^{2+}$ indirect transition [30]. The notable feature of this optical pattern is that, the prepared TTMOs nanocomposite powder revealed good absorbance behaviour in the both UV and visible regions without sing of absorption edge. This result confirms the synthesized ternary nanocomposite is driven by both UV and visible light simultaneously with a good efficiency. Figure 6 shows the Tauc's plot for evaluation of the energy gap of the $\mathrm{ZnFe}_{2} \mathrm{O}_{4} / \alpha-$ $\mathrm{Fe}_{2} \mathrm{O}_{3} / \mathrm{ZnO}$ nanocomposite powder calcined at $500{ }^{\circ} \mathrm{C}$ using UV-Visible spectroscopy data. The optical band gap energy $\left(\mathrm{E}_{\mathrm{g}}\right)$ is given by the below classical relation known as Tauc's method [51]:

$$
\alpha(v) \mathrm{h} v=\mathrm{A}\left(\mathrm{h} v-\mathrm{E}_{g}\right)^{n}
$$

Where $\alpha(v)$ is absorption coefficient, A is a proportionality constant, $\mathrm{h}$ is Planck's constant, $v$ is the incident photon's frequency. The value of $n$ depends on the type of optical transition between valance band and conduction band. For allowed direct and indirect transitions $\mathrm{n}=1 / 2$ and 2 respectively.

Absorption coefficient $\alpha(v)$ has been defined by the BeerLambert's law:

$$
\alpha(v)=2.303 \frac{A_{b s}(v)}{L}
$$

Where $A_{b s}(v)$ is the measured absorbance corresponding for each incident frequency and $\mathrm{L}$ is the optical path length which

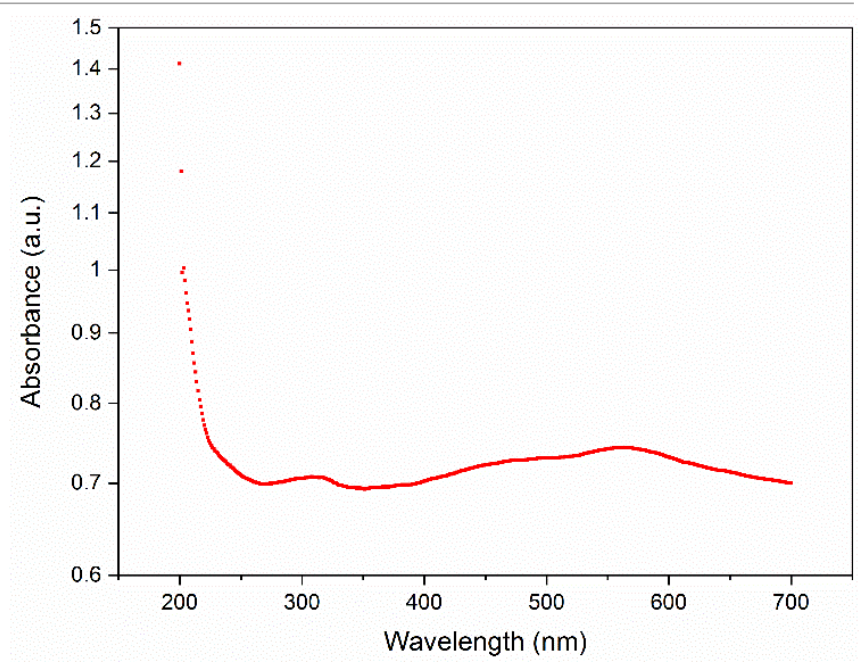

Fig.5 UV-Visible absorption spectrum of the $\mathrm{ZnFe}_{2} \mathrm{O}_{4} / \alpha$ $\mathrm{Fe}_{2} \mathrm{O}_{3} / \mathrm{ZnO}$ nanocomposite powder prepared by coprecipitation method calcined at $500{ }^{\circ} \mathrm{C}$
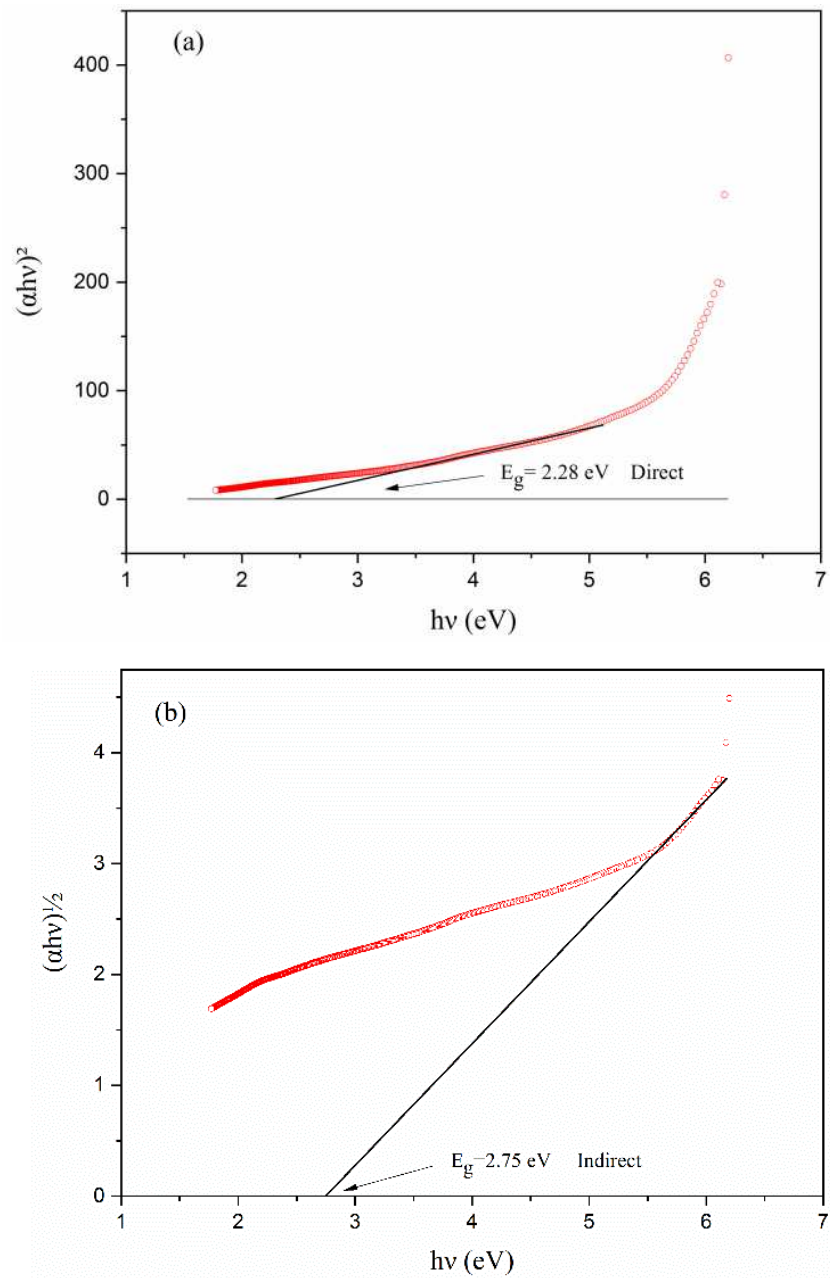

Fig.6 Tauc's plot for estimating optical band gap energy of the $\mathrm{ZnFe} 2 \mathrm{O} 4 / \alpha-\mathrm{Fe}_{2} \mathrm{O}_{3} / \mathrm{ZnO}$ nanocomposite powder calcined at $500{ }^{\circ} \mathrm{C}$ using UV-Visible absorption data (a) direct optical band gap energy (DBG) and (b) indirect band gap energy (IBG)

was assumed to be $1 \mathrm{~cm}$, equal to the thickness of quartz cuvette of spectrometer. The band gap energy of the products can be determined by plotting $(\alpha h v)^{2}$ and $(\alpha h v)^{1 / 2}$ vs $h v$, for allowed direct and indirect transitions, respectively. Extrapolating the straight-line portion of the plot to the photon energy axis at the $\alpha \mathrm{h} v^{1 / n}=0$ gives the $\mathrm{E}_{\mathrm{g}}$ values. The controversial part of this method is determining the linear region which may cause inaccuracy in some cases specially in these types of aqueous solution nanocomposite materials in expose of incident wavelengths [52]. Considering this fact, as is shown in Figure $6(\mathrm{a}, \mathrm{b})$ the best fittings were have been tried for extrapolations. As the result, the direct optical band gap energy of produced nanocomposite powder was estimated to be around $2.28 \mathrm{eV}$ and for indirect allowed band gap the value was $2.75 \mathrm{eV}$.

\section{CONCLUSION}

Pure ternary semiconducting nanocomposite of $\mathrm{ZnFe}_{2} \mathrm{O}_{4}, \alpha$ $\mathrm{Fe}_{2} \mathrm{O}_{3}$ and $\mathrm{ZnO}$ was successfully prepared via coprecipitation 
method. The XRD, SEM and UV-Visible analysis demonstrated formation of uniform and homogenous of these transition metal oxide nanoparticles with crystallite size between $25 \mathrm{~nm}$ to $39 \mathrm{~nm}$. The effects of post-synthesis thermal treatment on physical properties was also investigated in the present work. The Results indicate rise in the thermal treatment temperature yielded in formation new planes in $\mathrm{ZnFe}_{2} \mathrm{O}_{4}$ and $\mathrm{ZnO}$ crystals structures. In contrast this change resulted in vanishing planes with weak intensity of $\alpha-\mathrm{Fe}_{2} \mathrm{O}_{3}$. Crystallite size and lattice constant were reveals are influenced by calcination temperature. Particle size in all samples under different temperatures were estimated below $93 \mathrm{~nm}$ and the most uniformity in size observed in sample

\section{REFERENCES}

[1] Tama, A.M.; Das, S.; Dutta, S.; Bhuyan, M.D.I.; Islam, M.N.; Basith, M.A. $\mathrm{MoS}_{2}$ nanosheet incorporated $\alpha-$ $\mathrm{Fe}_{2} \mathrm{O}_{3} / \mathrm{ZnO}$ nanocomposite with enhanced photocatalytic dye degradation and hydrogen production ability. RSC Adv., 2019, 9, 40357-40367.

[2] Sun, M.; Liu, H.; Liu, Y.; Qu, J.; Li, J. Graphene-based transition metal oxide nanocomposites for the oxygen reduction reaction. Nanoscale, 2015, 7, 1250-1269.

[3] Jeseentharani, V.; George, M.; Jeyaraj, B.; Dayalan, A.; Nagaraja, K.S. Synthesis of metal ferrite $\left(\mathrm{MFe}_{2} \mathrm{O}_{4}\right.$, $\mathrm{M}=\mathrm{Co}, \mathrm{Cu}, \mathrm{Mg}, \mathrm{Ni}, \mathrm{Zn}$ ) nanoparticles as humidity sensor materials. Journal of Experimental Nanoscience, 2013, 8, 358-370.

[4] Modafferi, V.; Santangelo, S.; Fiore, M.; Fazio, E.; Triolo, C.; Patanè, S.; Ruffo, R.; Musolino, M.G. Transition Metal Oxides on Reduced Graphene Oxide Nanocomposites: Evaluation of Physicochemical Properties. Journal of Nanomaterials, 2019, 9, 1-9.

[5] Mao, N. Investigating the Heteronjunction between $\mathrm{ZnO} / \mathrm{Fe}_{2} \mathrm{O}_{3}$ and $\mathrm{g}-\mathrm{C}_{3} \mathrm{~N}_{4}$ for an Enhanced Photocatalytic $\mathrm{H} 2$ production under visible-light irradiation. Scientific reports, 2019, 9, 12383.

[6] Uma, K.; Balu, S.; Pan, G.-T.; Yang, T. Assembly of $\mathrm{ZnO}$ Nanoparticles on $\mathrm{SiO}_{2} @ \alpha-\mathrm{Fe}_{2} \mathrm{O}_{3}$ Nanocomposites for an Efficient Photo-Fenton Reaction. Inorganics, 2018, 6, 90.

[7] Zangeneh Kamali, K.; Alagarsamy, P.; Huang, N.M.; Ong, B.H.; Lim, H.N. Hematite NanoparticlesModified Electrode Based Electrochemical Sensing Platform for Dopamine. The Scientific World Journal, 2014, 2014, 1-13.

[8] Li, J.; Liu, Z.; Zhu, Z. Magnetically separable $\mathrm{ZnFe}_{2} \mathrm{O}_{4}, \mathrm{Fe}_{2} \mathrm{O}_{3} / \mathrm{ZnFe}_{2} \mathrm{O}_{4}$ and $\mathrm{ZnO} / \mathrm{ZnFe}_{2} \mathrm{O}_{4}$ hollow nanospheres with enhanced visible photocatalytic properties. $R S C A d v, \mathbf{2 0 1 4}, 4,51302-51308$.

[9] Xu, Y.; Wu, S.; Li, X.; Huang, Y.; Wang, Z.; Han, Y.; Wu, J.; Meng, H.; Zhang, X. Synthesis, characterization, and photocatalytic degradation properties of $\mathrm{ZnO} / \mathrm{ZnFe}_{2} \mathrm{O}_{4}$ magnetic heterostructures. New J. Chem., 2017, 41, 15433-15438.

[10] Li, X.; Jin, B.; Huang, J.; Zhang, Q.; Peng, R.; Chu, S. calcined at $600{ }^{\circ} \mathrm{C}$. The DBG of the composite was estimated to be $2.28 \mathrm{eV}$ for allowed direct optical transitions and 2.75 $\mathrm{eV}$ in the case of allowed indirect band gap (IBG). Optical characterization illustrated that the product as an aqueous composite can be driven by both UV and visible wavelengths with a good efficiency.

\section{CONFLICT OF INTEREST}

There are no conflicts to declare.

$\mathrm{Fe}_{2} \mathrm{O}_{3} / \mathrm{ZnO} / \mathrm{ZnFe}_{2} \mathrm{O}_{4}$ composites for the efficient photocatalytic degradation of organic dyes under visible light. Solid State Sciences, 2018, 80, 6-14.

[11] Dhal, J.P.; Mishra, B.G.; Hota, G. Hydrothermal synthesis and enhanced photocatalytic activity of ternary $\mathrm{Fe}_{2} \mathrm{O}_{3} / \mathrm{ZnFe}_{2} \mathrm{O}_{4} / \mathrm{ZnO}$ nanocomposite through cascade electron transfer. RSC Adv., 2015, 5, 5807258083.

[12] X. Yu, X.; Z. Dong, F.; Dong, B.; Liu, L.; Wu, Y. High visible-light photocatalytic performance of natural hematite ore composited with $\mathrm{ZnO}$ nanomaterials. AML, 2017, 8, 393-397.

[13] Xie, J.; Zhou, Z.; Lian, Y.; Hao, Y.; Li, P.; Wei, Y. Synthesis of $\alpha-\mathrm{Fe}_{2} \mathrm{O}_{3} / \mathrm{ZnO}$ composites for photocatalytic degradation of pentachlorophenol under UV-vis light irradiation. Ceramics International, 2015, 41, 2622-2625.

[14] Manzoor, N.; Sadiq, M.; Naqvi, M.; Sikandar, U.; Naqvi, S.R. Experimental Study of $\mathrm{CO}_{2}$ Conversion into Methanol by Synthesized Photocatalyst $\left(\mathrm{ZnFe}_{2} \mathrm{O}_{4} / \mathrm{TiO}_{2}\right)$ Using Visible Light as an Energy Source. Catalysts, 2020, 10, 163.

[15] Taffa, D.H.; Dillert, R.; Ulpe, A.C.; Bauerfeind, K.C.L.; Bredow, T.; Bahnemann, D.W.; Wark, M. Photoelectrochemical and theoretical investigations of spinel type ferrites $\left(\mathrm{MxFe}_{3}-\mathrm{xO}_{4}\right)$ for water splitting: a mini-review. J. Photon. Energy, 2016, 7, 12009.

[16] Dom, R.; Chary, A.S.; Subasri, R.; Hebalkar, N.Y.; Borse, P.H. Solar hydrogen generation from spinel $\mathrm{ZnFe}_{2} \mathrm{O}_{4}$ photocatalyst: effect of synthesis methods. Int. J. Energy Res., 2015, 39, 1378-1390.

[17] Hussain, S.; Hussain, S.; Waleed, A.; Tavakoli, M.M.; Yang, S.; Rauf, M.K.; Fan, Z.; Nadeem, M.A. Spray Pyrolysis Deposition of $\mathrm{ZnFe}_{2} \mathrm{O}_{4} / \mathrm{Fe}_{2} \mathrm{O}_{3}$ Composite Thin Films on Hierarchical 3-D Nanospikes for Efficient Photoelectrochemical Oxidation of Water. $J$. Phys. Chem. C, 2017, 121, 18360-18368.

[18] Jiang, J.; Pi, J.; Cai, J. The Advancing of Zinc Oxide Nanoparticles for Biomedical Applications. Bioinorganic chemistry and applications, 2018, 2018, 1062562. 
[19] Madhumitha, G.; Elango, G.; Roopan, S.M. Biotechnological aspects of $\mathrm{ZnO}$ nanoparticles: overview on synthesis and its applications. Applied microbiology and biotechnology, 2016, 100, 571-581.

[20] Hoque, S.M.; Hossain, M.S.; Choudhury, S.; Akhter, S.; Hyder, F. Synthesis and characterization of $\mathrm{ZnFe}_{2} \mathrm{O}_{4}$ nanoparticles and its biomedical applications. Materials letters, 2016, 162, 60-63.

[21] Vallabani, N.V.S.; Singh, S. Recent advances and future prospects of iron oxide nanoparticles in biomedicine and diagnostics. 3 Biotech, 2018, 8, 279.

[22] Arias, L.S.; Pessan, J.P.; Vieira, A.P.M.; Lima, T.M.T. de; Delbem, A.C.B.; Monteiro, D.R. Iron Oxide Nanoparticles for Biomedical Applications: A Perspective on Synthesis, Drugs, Antimicrobial Activity, and Toxicity. Antibiotics (Basel, Switzerland), 2018, 7.

[23] Dinali, R.; Ebrahiminezhad, A.; Manley-Harris, M.; Ghasemi, Y.; Berenjian, A. Iron oxide nanoparticles in modern microbiology and biotechnology. Critical reviews in microbiology, 2017, 43, 493-507.

[24] Zhang, X.; Li, H.; Wang, S.; Fan, F.-R.F.; Bard, A.J. Improvement of Hematite as Photocatalyst by Doping with Tantalum. J. Phys. Chem. C, 2014, 118, 1684216850.

[25] Cha, H.G.; Noh, H.S.; Kang, M.J.; Kang, Y.S. Photocatalysis: progress using manganese-doped hematite nanocrystals. New J. Chem., 2013, 37, 4004.

[26] Tamirat, A.G.; Rick, J.; Dubale, A.A.; Su, W.-N.; Hwang, B.-J. Using hematite for photoelectrochemical water splitting: a review of current progress and challenges. Nanoscale horizons, 2016, 1, 243-267.

[27] Suman; Chahal, S.; Kumar, A.; Kumar, P. Zn Doped $\alpha-$ $\mathrm{Fe}_{2} \mathrm{O}_{3}$ : An Efficient Material for UV Driven Photocatalysis and Electrical Conductivity. Crystals, 2020, 10, 273.

[28] Borysiewicz, M.A. ZnO as a Functional Material, a Review. Crystals, 2019, 9, 505-534.

[29] Chen, C.; Li, Z.; Lin, H.; Wang, G.; Liao, J.; Li, M.; Lv, S.; Li, W. Enhanced visible light photocatalytic performance of $\mathrm{ZnO}$ nanowires integrated with $\mathrm{CdS}$ and Ag2S. Dalton transactions (Cambridge, England: 2003), 2016, 45, 3750-3758.

[30] Granone, L.I.; Ulpe, A.C.; Robben, L.; Klimke, S.; Jahns, M.; Renz, F.; Gesing, T.M.; Bredow, T.; Dillert, R.; Bahnemann, D.W. Effect of the degree of inversion on optical properties of spinel $\mathrm{ZnFe}_{2} \mathrm{O}_{4}$. Physical chemistry chemical physics: PCCP, 2018, 20, 2826728278.

[31] Song, H.; Zhu, L.; Li, Y.; Lou, Z.; Xiao, M.; Ye, Z. Preparation of $\mathrm{ZnFe}_{2} \mathrm{O}_{4}$ nanostructures and highly efficient visible-light-driven hydrogen generation with the assistance of nanoheterostructures. J. Mater. Chem. A, 2015, 3, 8353-8360.

[32] Guo, H.; Zhang, Y.; Marschilok, A.C.; Takeuchi, K.J.; Takeuchi, E.S.; Liu, P. A first principles study of spinel $\mathrm{ZnFe}_{2} \mathrm{O}_{4}$ for electrode materials in lithium-ion batteries. Physical chemistry chemical physics: PCCP, 2017, 19, 26322-26329.

[33] Gomes, J.A.; Azevedo, G.M.; Depeyrot, J.; MestnikFilho, J.; da Silva, G.J.; Tourinho, F.A.; Perzynski, R. $\mathrm{ZnFe}_{2} \mathrm{O}_{4}$ nanoparticles for ferrofluids: A combined XANES and XRD study. Journal of Magnetism and Magnetic Materials, 2011, 323, 1203-1206.

[34] Kombaiah, K.; Vijaya, J.J.; Kennedy, L.J.; Bououdina, M. Optical, magnetic and structural properties of $\mathrm{ZnFe}_{2} \mathrm{O}_{4}$ nanoparticles synthesized by conventional and microwave assisted combustion method: A comparative investigation. Optik, 2017, 129, 57-68.

[35] Thiagarajan, S.; Sanmugam, A.; Vikraman, D. Facile Methodology of Sol-Gel Synthesis for Metal Oxide Nanostructures. In: Recent Applications in Sol-Gel Synthesis. Chandra, U., Ed.; InTech, 2017.

[36] Hernández, A.; Maya, L.; Sánchez-Mora, E.; Sánchez, E.M. Sol-gel synthesis, characterization and photocatalytic activity of mixed oxide $\mathrm{ZnO}-\mathrm{Fe}_{2} \mathrm{O}_{3} . J$ Sol-Gel Sci Technol, 2007, 42, 71-78.

[37] Maya-Treviño, M.L.; Villanueva-Rodríguez, M.; Guzmán-Mar, J.L.; Hinojosa-Reyes, L.; HernándezRamírez, A. Comparison of the solar photocatalytic activity of $\mathrm{ZnO}-\mathrm{Fe}_{2} \mathrm{O}_{3}$ and $\mathrm{ZnO}-\mathrm{Fe}(0)$ on 2,4-D degradation in a CPC reactor. Photochemical \& photobiological sciences: Official journal of the European Photochemistry Association and the European Society for Photobiology, 2015, 14, 543549.

[38] Zhang, W.; Yang, Y.; Ziemann, E.; Be'er, A.; Bashouti, M.Y.; Elimelech, M.; Bernstein, R. One-step sonochemical synthesis of a reduced graphene oxide $\mathrm{ZnO}$ nanocomposite with antibacterial and antibiofouling properties. Environ. Sci.: Nano, 2019, 6, 3080-3090.

[39] Xu, H.; Zeiger, B.W.; Suslick, K.S. Sonochemical synthesis of nanomaterials. Chemical Society reviews, 2013, 42, 2555-2567.

[40] Feng, J.; Wang, Y.; Zou, L.; Li, B.; He, X.; Ren, Y.; Lv, Y.; Fan, Z. Synthesis of magnetic $\mathrm{ZnO} / \mathrm{ZnFe}_{2} \mathrm{O}_{4}$ by a microwave combustion method, and its high rate of adsorption of methylene blue. Journal of colloid and interface science, 2015, 438, 318-322.

[41] Manikandan, A.; Judith Vijaya, J.; Sundararajan, M.; Meganathan, C.; Kennedy, L.J.; Bououdina, M. Optical and magnetic properties of $\mathrm{Mg}$-doped $\mathrm{ZnFe}_{2} \mathrm{O}_{4}$ nanoparticles prepared by rapid microwave combustion method. Superlattices and Microstructures, 2013, 64, 118-131.

[42] Sebehanie, K.G. Comparative Study of $\mathrm{ZnO} / \mathrm{Fe}_{2} \mathrm{O}_{3}$ Nanocomposite Sensitized with Natural Pigments for Dye Sensitized Solar Cell. IJHIT, 2017, 10, 199-214.

[43] Yao, J.; Yan, J.; Huang, Y.; Li, Y.; Xiao, S.; Xiao, J. Preparation of $\mathrm{ZnFe}_{2} \mathrm{O}_{4} / \alpha$ - $\mathrm{Fe}_{2} \mathrm{O}_{3}$ Nanocomposites From Sulfuric Acid Leaching Liquor of Jarosite Residue and Their Application in Lithium-Ion Batteries. Frontiers in chemistry, 2018, 6, 442. 
[44] Guo, T.; Yao, M.-S.; Lin, Y.-H.; Nan, C.-W. A comprehensive review on synthesis methods for transition-metal oxide nanostructures. CrystEngComm, 2015, 17, 3551-3585.

[45] Iqbal, F.; Mutalib, M.I.A.; Shaharun, M.S.; khan, M.; Abdullah, B. Synthesis of $\mathrm{ZnFe}_{2} \mathrm{O}_{4}$ Using sol-gel Method: Effect of Different Calcination Parameters. Procedia Engineering, 2016, 148, 787-794.

[46] Fouad, D.E.; Zhang, C.; El-Didamony, H.; Yingnan, L.; Mekuria, T.D.; Shah, A.H. Improved size, morphology and crystallinity of hematite $\left(\alpha-\mathrm{Fe}_{2} \mathrm{O}_{3}\right)$ nanoparticles synthesized via the precipitation route using ferric sulfate precursor. Results in Physics, 2019, 12, 1253-1261.

[47] Al-Hada, N.M.; Saion, E.; Shaari, A.H.; Kamarudin, M.A.; Gene, S.A. The Influence of Calcination Temperature on the Formation of Zinc Oxide Nanoparticles by Thermal-Treatment. AMM, 2013, 446-447, 181-184.

[48] Yadav, R.S.; Kuřitka, I.; Vilcakova, J.; Urbánek, P.; Machovsky, M.; Masař, M.; Holek, M. Structural, magnetic, optical, dielectric, electrical and modulus spectroscopic characteristics of $\mathrm{ZnFe}_{2} \mathrm{O}_{4}$ spinel ferrite nanoparticles synthesized via honey-mediated sol-gel combustion method. Journal of Physics and Chemistry of Solids, 2017, 110, 87-99.

[49] Bindu, P.; Thomas, S. Optical Properties of $\mathrm{ZnO}$ Nanoparticles Synthesised from a Polysaccharide and ZnCl 2. Acta Phys. Pol. A, 2017, 131, 1474-1478.

[50] Shamhari, N.M.; Wee, B.S.; Chin, S.F.; Kok, K.Y. Synthesis and Characterization of Zinc Oxide Nanoparticles with Small Particle Size Distribution. ACSi, 2018, 65, 578-585.

[51] Tauc, J.; Grigorovici, R.; Vancu, A. Optical Properties and Electronic Structure of Amorphous Germanium. phys. stat. sol. (b), 1966, 15, 627-637.

[52] Viezbicke, B.D.; Patel, S.; Davis, B.E.; Birnie, D.P. Evaluation of the Tauc method for optical absorption edge determination: $\mathrm{ZnO}$ thin films as a model system. phys. stat. sol. (b), 2015, 252, 1700-1710. 
Figures

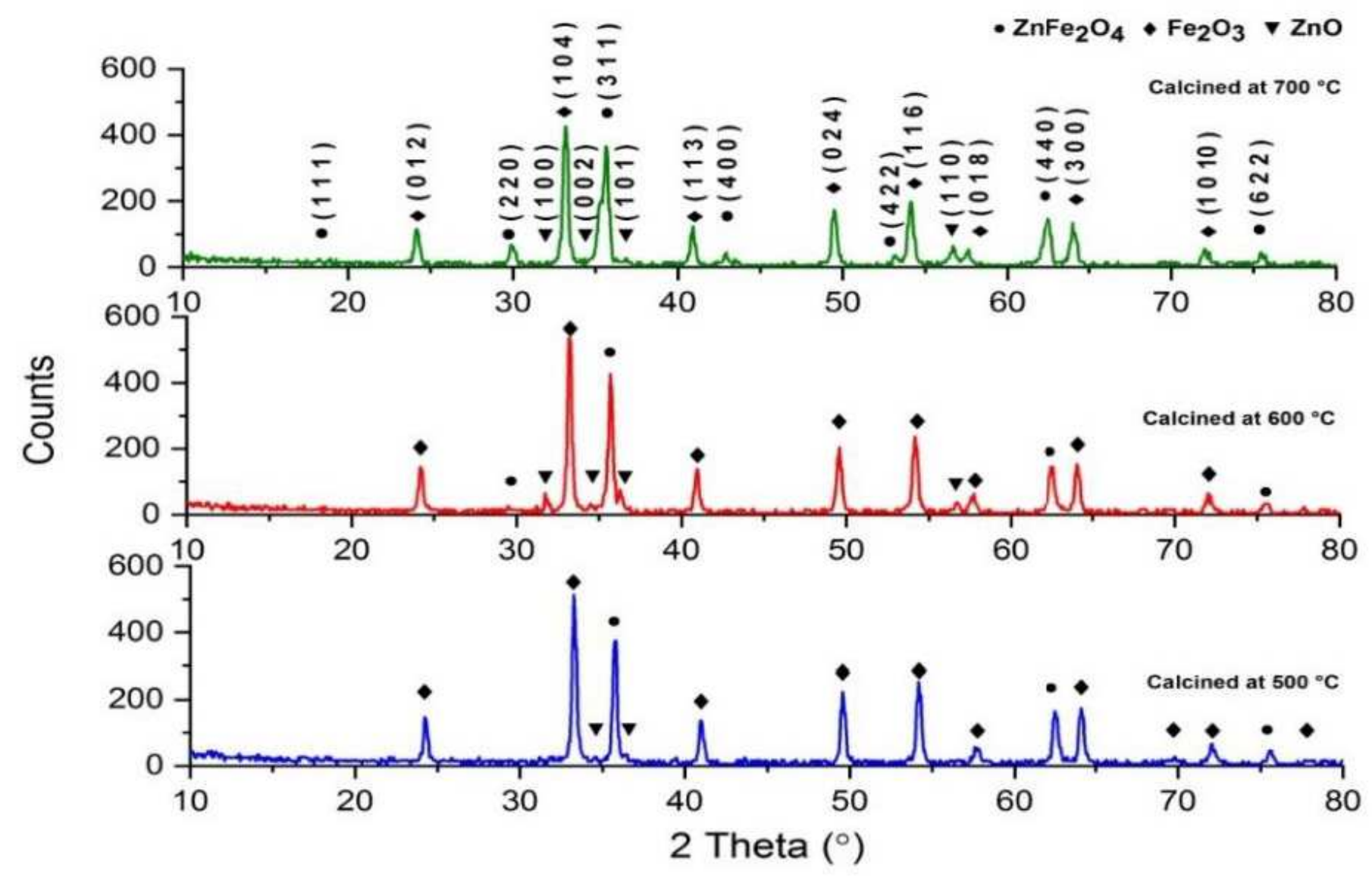

Figure 1

XRD patterns of ZnFe204/a-Fe2O3/ZnO nanocomposite calcined at $500{ }^{\circ} \mathrm{C}, 600{ }^{\circ} \mathrm{C}$ and $700{ }^{\circ} \mathrm{C}$ 


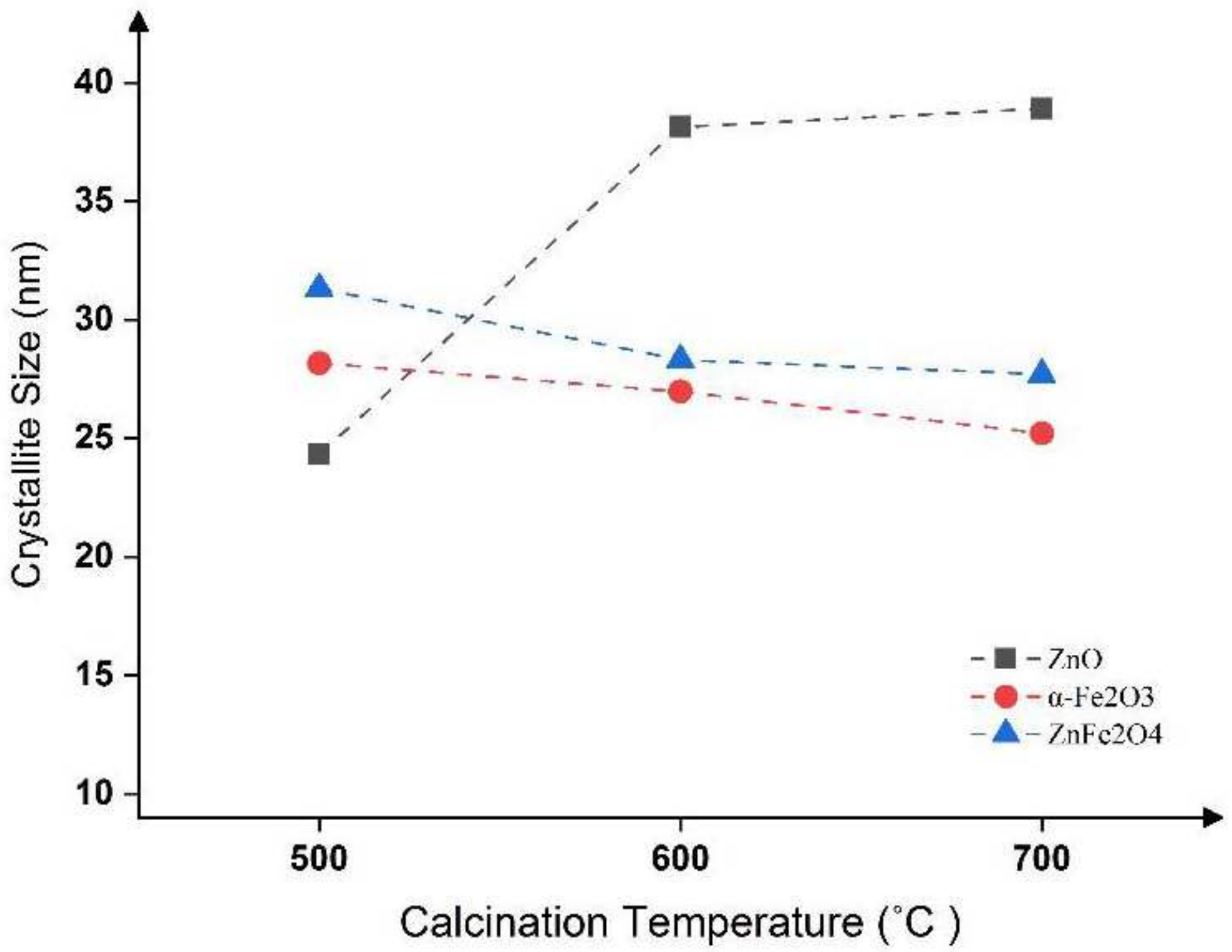

Figure 2

Effect of calcination temperature on the crystallite size of the ZnFe2O4/a-Fe2O3/ZnO composite components 

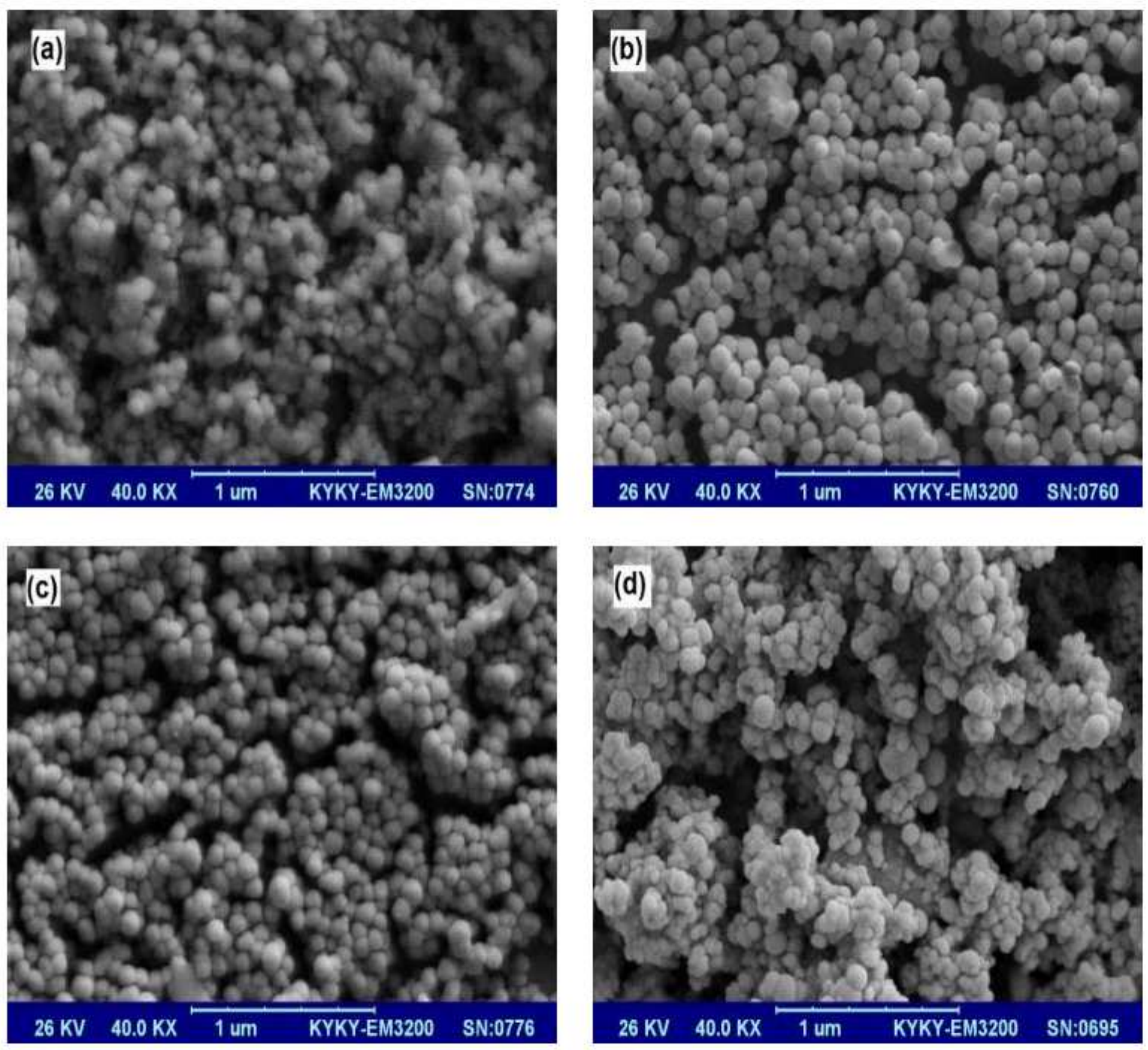

\section{Figure 3}

SEM images of the $\mathrm{ZnFe} 204 / \mathrm{a}-\mathrm{Fe} 2 \mathrm{O} / \mathrm{ZnO}$ nanocomposite powders: (a) as-prepared, and after calcination at (b) $500{ }^{\circ} \mathrm{C},(\mathrm{c}) 600^{\circ} \mathrm{C}$ and (d) $700{ }^{\circ} \mathrm{C}$ 


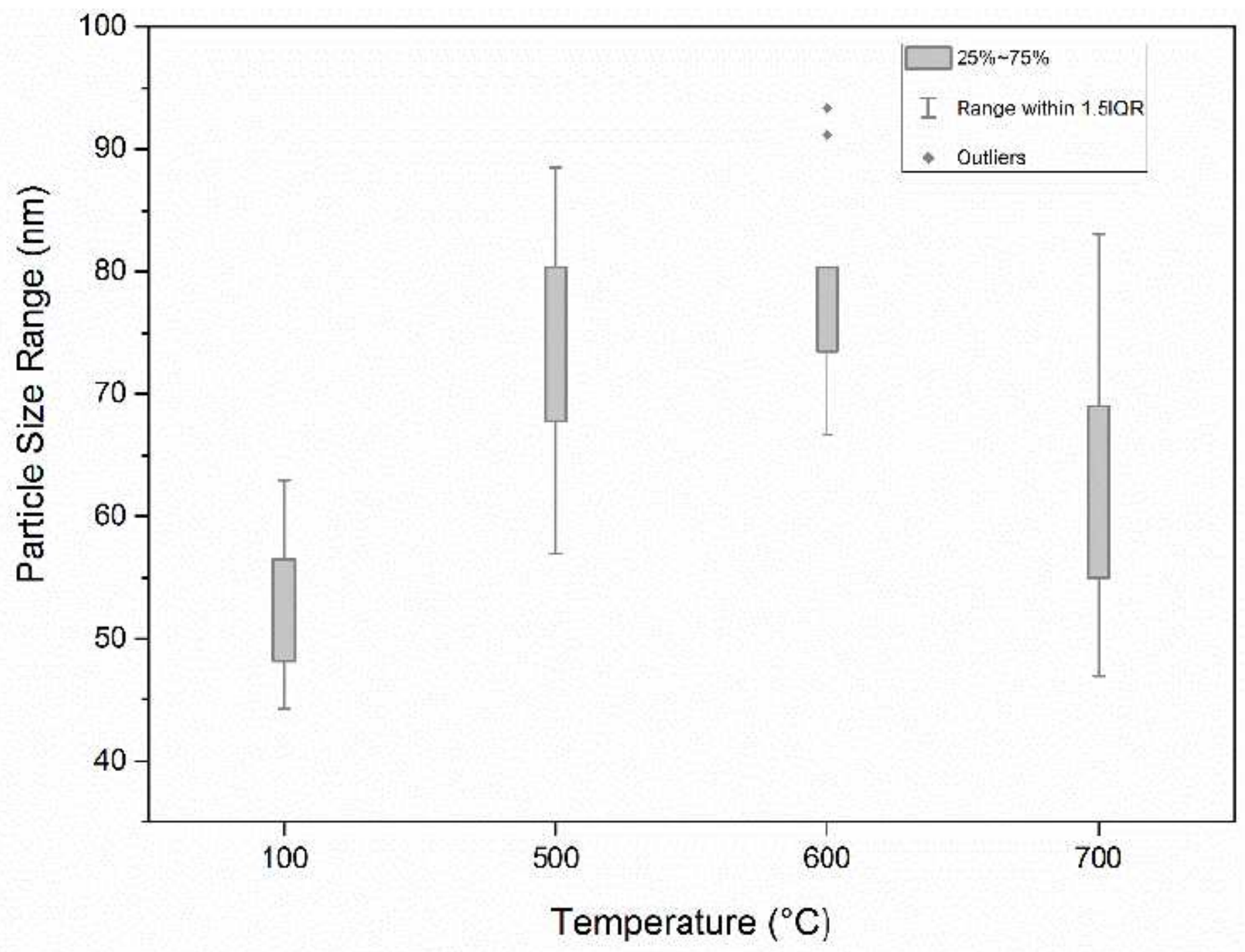

Figure 4

Size range of the $\mathrm{ZnFe} 2 \mathrm{O} 4 / \mathrm{a}-\mathrm{Fe} 2 \mathrm{O} / \mathrm{ZnO}$ nanoparticles versus calcination temperature 


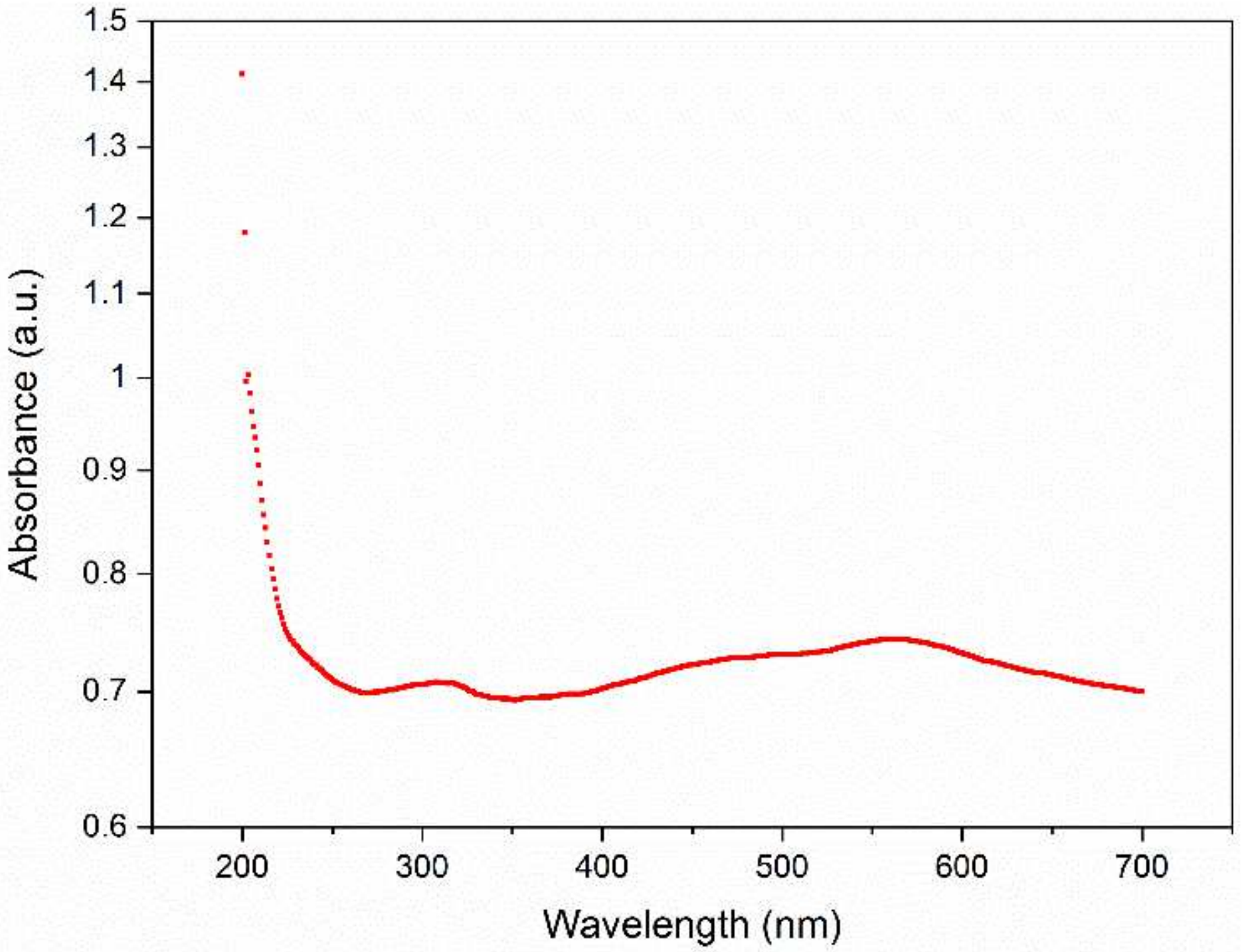

Figure 5

UV-Visible absorption spectrum of the ZnFe204/a-Fe2O3/ZnO nanocomposite powder prepared by coprecipitation method calcined at $500^{\circ} \mathrm{C}$ 

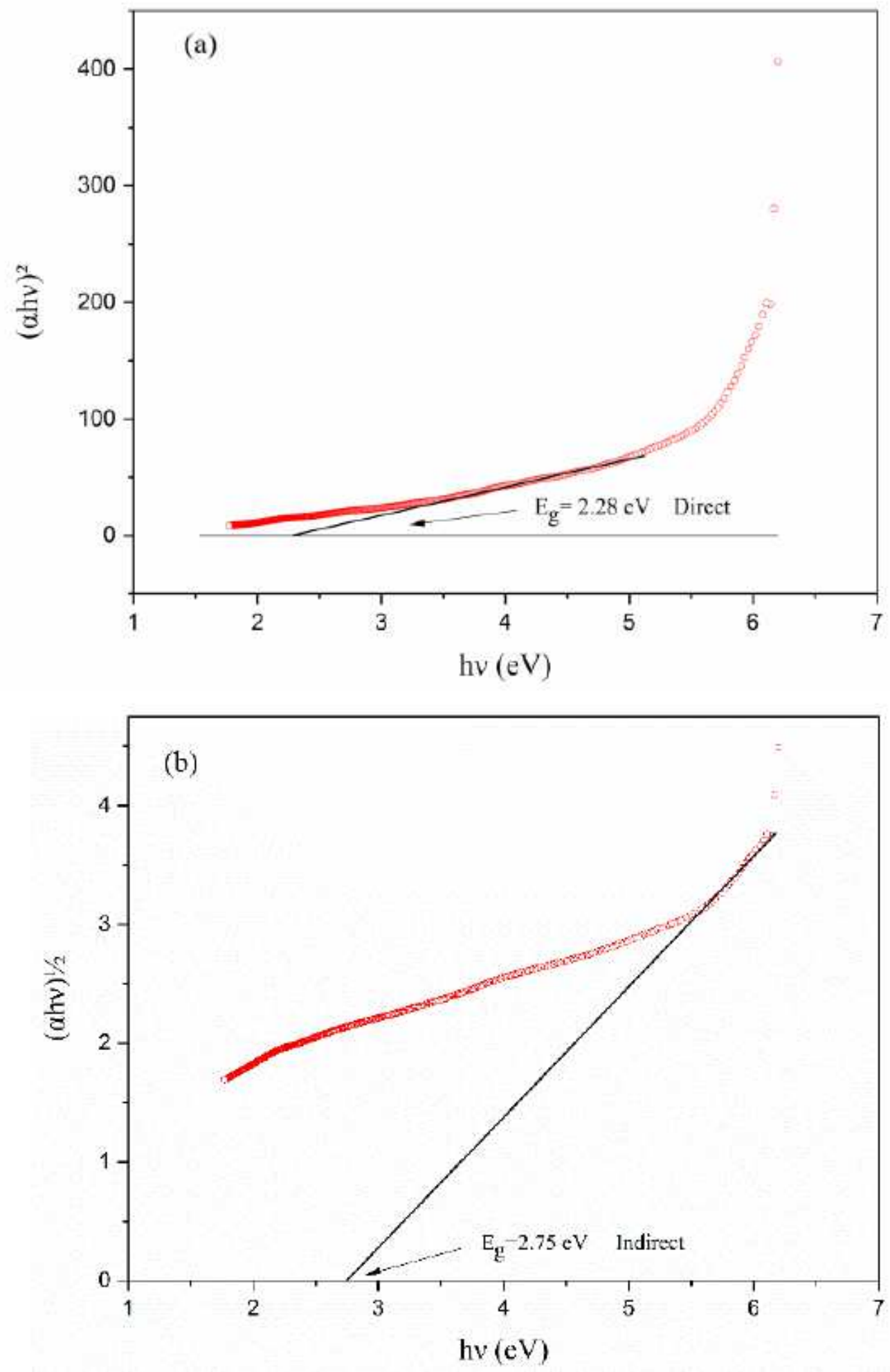

Figure 6

Tauc's plot for estimating optical band gap energy of the ZnFe204/a-Fe203/ZnO nanocomposite powder calcined at $500^{\circ} \mathrm{C}$ using UV-Visible absorption data (a) direct optical band gap energy (DBG) and (b) indirect band gap energy (IBG) 